\title{
Assessment of binary metallic-based nanoparticles addition effects on performance, emission, and vibration behaviors of a diesel engine
}

\author{
Abdulkadir Yasar ${ }^{1}$, Sinan Keiyinci2 ${ }^{*}$, Mehmet Bilgili³ $^{3}$ \\ 1,3 Department of Mechanical Engineering, Faculty of Ceyhan Engineering, Cukurova University, Ceyhan, Adana, Turkey, ${ }^{2}$ Department of Automotive \\ Engineering, Faculty of Engineering, Cukurova University, Adana, Turkey
}

Orcid: A. Yaşar (0000-0002-I548-2386), S. Keiyinci (0000-0003-2948-3846), M. Bilgili (0000-0002-5339-6I20)

Abstract: This paper reveals the results of metallic-based nanoparticle's effect on the performance, emission, and vibration of a diesel engine. Various metal-based nanoparticles such as Nickel (II) nitrate hexahydrate $\left(\mathrm{Ni}\left(\mathrm{NO}_{3}\right)_{2} \cdot 6 \mathrm{H}_{2} \mathrm{O}\right)$, Silver nitrate $(\mathrm{AgNO})$,

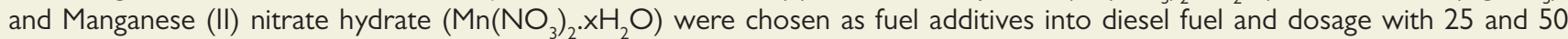
ppm. In experimental tests, to identify the combined effect of silver nitrate on manganese and nickel, silver nitrate was chosen as a reference element in each mixture, thereby creating 4 different test samples. Engine tests were conducted in a single-cylinder diesel engine. The results revealed that values of specific fuel consumption, carbon monoxide, hydrocarbon, and oxides of nitrogen emissions with the increase in the dosage level of nanoparticles into diesel fuel were reduced considerably for all test fuels. Also, vibration and sound pressure level features of the diesel engine were reduced with the increasing dosage of nanoparticle additives.

Keywords: diesel engine; nanoparticle; emission; vibration; additive; combined effect.

\section{Introduction}

Internal combustion engines (ICEs) have the ability to convert chemical energy supplied by fuel with the presence of an oxidizer into useful mechanical energy. In ICEs, this conversion is achieved mainly in two ways according to ignition sources attributed as spark ignition (SI) and compression ignition (CI). CI engines (diesel) are commonly utilized in wider application areas such as transportation, agriculture, generators, heavy-duty applications, etc. due to having advantages of high fuel conversion and thermal efficiency, higher torque levels, durability, and reliability compared to SI engines [1,2].

Releasing pollutants as a result of the combustion process in engines is inevitable. Therefore, scientists intensely make an effort to find ways for reducing these gases as much as possible [3]. Especially, concerns on health and environmental problems make regulations of emission strict and engine manufacturers have to obey these standards in order to commercialize their products.

There are various and alternative ways in order to promote the emission characteristics of the engine. Fuel features enhancement of conventional fossil fuels to obtain better combustion by use of alternative renewable fuels and fuel additives such as biofuels and nanoparticles, respectively, can be suggested as an effective way to decrease exhaust emission levels of engines [4].

Recently, researchers have shown interest in nanoparticle additives due to their remarkable properties such as acting as a combustion catalyst, exhibiting a higher surface area to volume ratio which ameliorates the combustion process and enhances performance, emission characteristics dependently [5]. Ozgur et al. [6] studied the effects of various metallic-based nanoparticle additions on oxides of nitrogen $\left(\mathrm{NO}_{x}\right)$ emission of a CI engine. They determined the optimum dosages of nanoparticles and accomplished that $\mathrm{NO}_{x}$ emissions were declined with the use of nanoparticles. El-seesy et al. [7] experimentally investigated the performance, emission, and combustion characteristics of a $\mathrm{CI}$ engine operated by jojoba biodiesel-diesel mixture with $\mathrm{Al}_{2} \mathrm{O}_{3}$ nanoparticle addition. $\mathrm{NO}_{x^{\prime}}$, $\mathrm{CO}, \mathrm{UHC}$, and smoke were reduced by $70 \%, 80 \%, 60 \%$, and $35 \%$, respectively at a dosage level of $20 \mathrm{mg} / 1 \mathrm{Al}_{2} \mathrm{O}_{3}$. On the other hand, a dosage level of $40 \mathrm{mg} / \mathrm{l} \mathrm{Al}_{2} \mathrm{O}_{3}$ demonstrated the best performance and combustion behavior. At this dose, brake specific fuel consumption 
was decreased by $12 \%$ while cylinder peak pressure, the maximum rate of pressure increases, and the maximum rate of heat release were increased by $4.5 \%, 4 \%$, and $4 \%$, respectively. Wu et al. [8] investigated the carbon-coated aluminum nanoparticle addition into biodiesel so as to observe the effects on the performance and emissions of the CI engine. Results demonstrated reductions in SFC (10\%), $\mathrm{NO}_{\mathrm{x}}(12 \%), \mathrm{CO}(9 \%)$ on average compared to neat biodiesel. Besides that, increments were obtained on total hydrocarbon compounds and particle numbers. Prabu [9] studied the working characteristic of a biodiesel-operated diesel engine with nanoparticle addition. $30 \mathrm{ppm}$ dose of alumina $\left(\mathrm{Al}_{2} \mathrm{O}_{3}\right)$ and cerium oxide $\left(\mathrm{CeO}_{2}\right)$ were used as additives and improved performance, combustion, and emission behavior were obtained with the presence of nanoparticles due to having high surface area/volume and enhanced chemical reactivity during combustion.

Besides the mentioned studies above, researches on noise and vibration characteristics of engines are another major issue to be emphasized. In the automotive sector, manufacturers aim to reduce engine vibration in order to meet the comfort conditions of passengers and to prevent the failure of mechanical parts [10]. Therefore, the noise and vibration behavior of the engine caused by the combustion phenomenon adversely affects both human health and the mechanical components of the system. Engines that have a higher compression ratio and rapid increasing combustion pressures particularly suffer from these problems.

In literature, there are various published studies related with vibration and noise characteristics of diesel engines that use a kind of primary fuel (conventional fossil fuel or renewable fuel) and nanoparticles as additives. Keskin et al. [11] evaluated the effects of palladium and acetylferrocene-based nanoparticle additives with diesel-biodiesel blends effects on vibration and emission behaviors of a diesel engine. They found that nanoparticle usage with a dose of $25 \mathrm{ppm}$ has improved the performance, emission, and vibration values of the engine. Yasar et al. [12] investigated the emission and vibration behaviors of a diesel engine operated by diesel fuel with metallic nanoparticles. Titanium (IV) dioxide $\left(\mathrm{TiO}_{2}\right)$, copper (II) nitrate $\left(\mathrm{Cu}\left(\mathrm{NO}_{3}\right)_{2}\right)$, and cerium (III) acetate hydrate $\left(\mathrm{Ce}\left(\mathrm{CH}_{3} \mathrm{CO}_{2}\right)_{3} \cdot \mathrm{H}_{2} \mathrm{O}\right)$ were selected as nanoparticles. 25 and $50 \mathrm{ppm}$ of nanoparticles mixed with diesel fuel via an ultrasonic processor to obtain homogenous dispersion of them in diesel fuel. In conclusion, cerium acetate hydrate can be suggested as an additive for diesel fuel since it diminishes $\mathrm{CO}$ and $\mathrm{HC}$ emission, noise, and vibration values of the engine. Agbulut et al. [13] searched the performance, emission, noise, and vibration characteristics of a diesel engine fueled with different types of metal oxide nanoparticles and biodiesel. Experiments were executed at a constant engine speed of $2000 \mathrm{rpm}$ and loads of 2.5, 5, 7.5, and $10 \mathrm{Nm}$. The waste cooking oil methyl ester was employed as biodiesel and aluminum oxide $\left(\mathrm{Al}_{2} \mathrm{O}_{3}\right)$, titanium oxide $\left(\mathrm{TiO}_{2}\right)$, and silicon oxide $\left(\mathrm{SiO}_{2}\right)$ were utilized as nanoparticles for preparing blends. They concluded that biodiesel which contains metal-oxide nanoparticles improves each of the engine parameters with respect to the pure usage of biodiesel in engines. In a previous study performed by authors [14], the effects of nanoparticles such as silver nitrate, manganese nitrate hydrate, and nickel nitrate hexahydrate on engine performance and emissions were studied separately at different dosing levels.

Although there are lots of studies that investigate the effects of various types of nanoparticle addition into fuels separately, there is a still gap including the combined effects of nanoparticles into conventional fuels. Furthermore, combined effects of oxygenated nanoparticles on both fuel properties and performance, emissions, and vibration parameters are required to be worked on by researchers. In this study, dual effects of $\mathrm{AgNO}_{3}-\left(\mathrm{Ni}\left(\mathrm{NO}_{3}\right)_{2} \cdot 6 \mathrm{H} 2 \mathrm{O}\right)$ and $\mathrm{AgNO}_{3}-\left(\mathrm{Mn}\left(\mathrm{NO}_{3}\right)_{2} \cdot \mathrm{xH}_{2} \mathrm{O}\right)$ dosed at 25 and $50 \mathrm{ppm}$ on performance, emission, and vibration characteristics of a diesel engine were evaluated.

\section{Materials and Methods}

The experimental studies are composed of two-stage which are the determination of physicochemical features of test fuels and performing engine tests to designate performance, emissions, and vibration characteristics of diesel engine. Test fuels were analyzed in Petroleum Research and Automotive Engineering Laboratories of the Automotive Engineering Department and engine tests were performed in the Mechanical Engineering Department Laboratory of Faculty of Ceyhan Engineering in Cukurova University.

\section{I. Test Fuel Preparation and Determination of Fuel Properties}

In this study, $\mathrm{Mn}\left(\mathrm{NO}_{3}\right)_{2} \cdot \mathrm{xH}_{2} \mathrm{O}, \mathrm{Ni}\left(\mathrm{NO}_{3}\right)_{2} \cdot 6 \mathrm{H}_{2} \mathrm{O}$, and $\mathrm{AgNO}_{3}$ metallic-based nanoparticles at the dose of 25 and $50 \mathrm{ppm}$ were used in order to add into diesel fuel. These nanoparticles were commercially supplied from Merck. Diesel fuel was utilized as a reference fuel to make comparative analyses. $\mathrm{AgNO}_{3}$ was taken as a reference additive in all blended fuels.

Diesel + $25 \mathrm{ppm} \mathrm{Ni}\left(\mathrm{NO}_{3}\right)_{2} \cdot 6 \mathrm{H}_{2} \mathrm{O}+25 \mathrm{ppm} \mathrm{AgNO}_{3}$, Diesel $+50 \mathrm{ppm} \mathrm{Ni}\left(\mathrm{NO}_{3}\right)_{2} \cdot 6 \mathrm{H}_{2} \mathrm{O}+50 \mathrm{ppm} \mathrm{AgNO}_{3}$, Diesel + $25 \mathrm{ppm} \mathrm{Mn}\left(\mathrm{NO}_{3}\right)_{2} \cdot \mathrm{xH}_{2} \mathrm{O}+25 \mathrm{ppm} \mathrm{AgNO}_{3}$, Diesel $+50 \mathrm{ppm} \mathrm{Mn}\left(\mathrm{NO}_{3}\right)_{2} \cdot \mathrm{xH}_{2} \mathrm{O}+50 \mathrm{ppm} \mathrm{AgNO}{ }_{3} \mathrm{fu}-$ els was represented by notations of DNiAg25, DNiAg50, DMnAg25, DMnAg50, correspondingly.

Ultrasonic processor (Sonic Vibra-Cell VC 750 model) which has a net power output of $750 \mathrm{~W}$, the frequency with $20 \mathrm{kHz}$, tip diameter of $13 \mathrm{~mm}$, and titanium alloy (Ti-6Al-4) was used to guarantee homogenous dispersion of nanoparticles in fuel as shown in Fig. 1. The blending 
process was achieved via an ultrasonic processor after each dose level of nanoparticles was measured with the help of a precision electronic balance with a sensitivity of 0.0001 g. The mixing process was conducted at $40 \%$ amplitude of the processor.

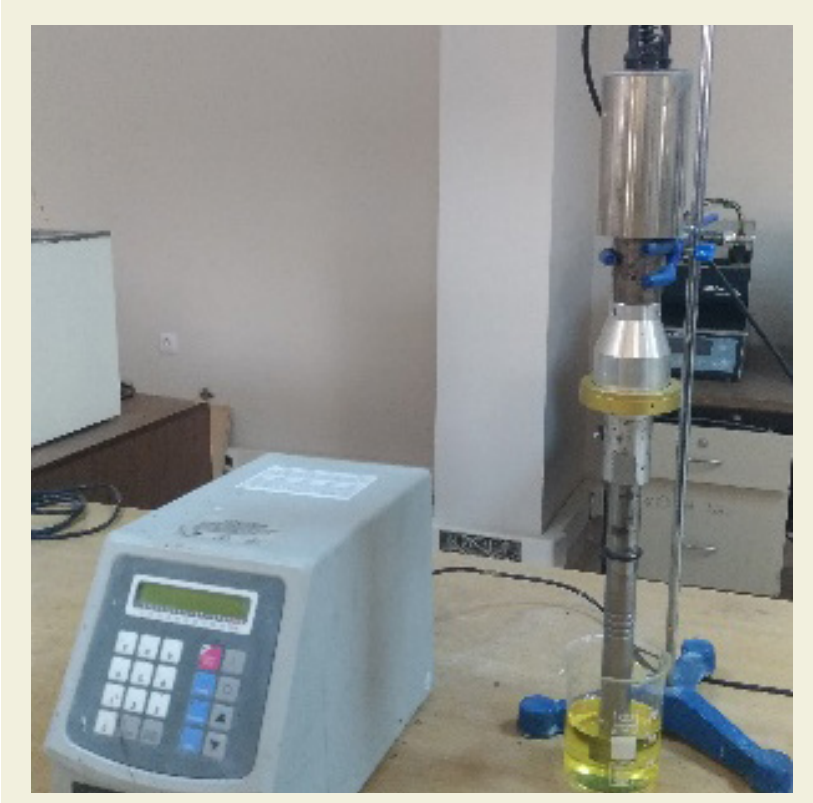

Figure 1. Sonic Ultrasonicator.

Table 1 summarizes the devices used for test fuel property analyses. Measurements of the fuel quality were evaluated with respect to TS EN 590 standards.

\begin{tabular}{|c|c|c|c|}
\hline Property & Device & $\begin{array}{l}\text { Accu- } \\
\text { racy }\end{array}$ & $\begin{array}{l}\text { Measuring } \\
\text { Range }\end{array}$ \\
\hline Cetane number & $\begin{array}{l}\text { Zeltex ZX } 440 \text { NIR } \\
\text { petroleum analyser }\end{array}$ & $3 \%$ & - \\
\hline Density & $\begin{array}{c}\text { Kyoto Electronics } \\
\text { DA-130 }\end{array}$ & $\begin{array}{l} \pm 0.01 \\
\mathrm{~g} / \mathrm{cm}^{3}\end{array}$ & - \\
\hline Viscosity & Tanaka AKV-202 & - & - \\
\hline $\begin{array}{l}\text { Lower heating } \\
\text { value }\end{array}$ & $\begin{array}{l}\text { IKA Werke C2000 } \\
\text { bomb calorimeter }\end{array}$ & $0.001 \mathrm{~K}$ & - \\
\hline Cloud point & Tanaka MPC-I02 & - & - \\
\hline Flashpoint & Tanaka APM-7 & - & - \\
\hline $\begin{array}{l}\text { Copper strip } \\
\text { corrosion }\end{array}$ & Koehler K25339 model & - & - \\
\hline Pour point & Tanaka MPC-102 & - & $\begin{array}{l}+51{ }^{\circ} \mathrm{C} \text { to }-40 \\
{ }^{\circ} \mathrm{C} \text { with tap } \\
\text { water of } 20^{\circ} \mathrm{C} \text {, } \\
+51{ }^{\circ} \mathrm{C} \text { to }-65 \\
{ }^{\circ} \mathrm{C} \text { with cooling } \\
\text { liquid of }-35^{\circ} \mathrm{C}\end{array}$ \\
\hline
\end{tabular}

\subsection{Engine Test Rig}

Engine tests were realized in a single-cylinder, 2-stroke, air-cooled compression ignition engine integrated with an AC dynamometer. The engine was operated at 1200 , $1600,2000,2400$, and $2800 \mathrm{rpm}$ at full load conditions for all test fuels. Tables 2-3 demonstrate the details of both the test engine and dynamometer, respectively. The schematic of test engine was illustrated in Fig. 2.

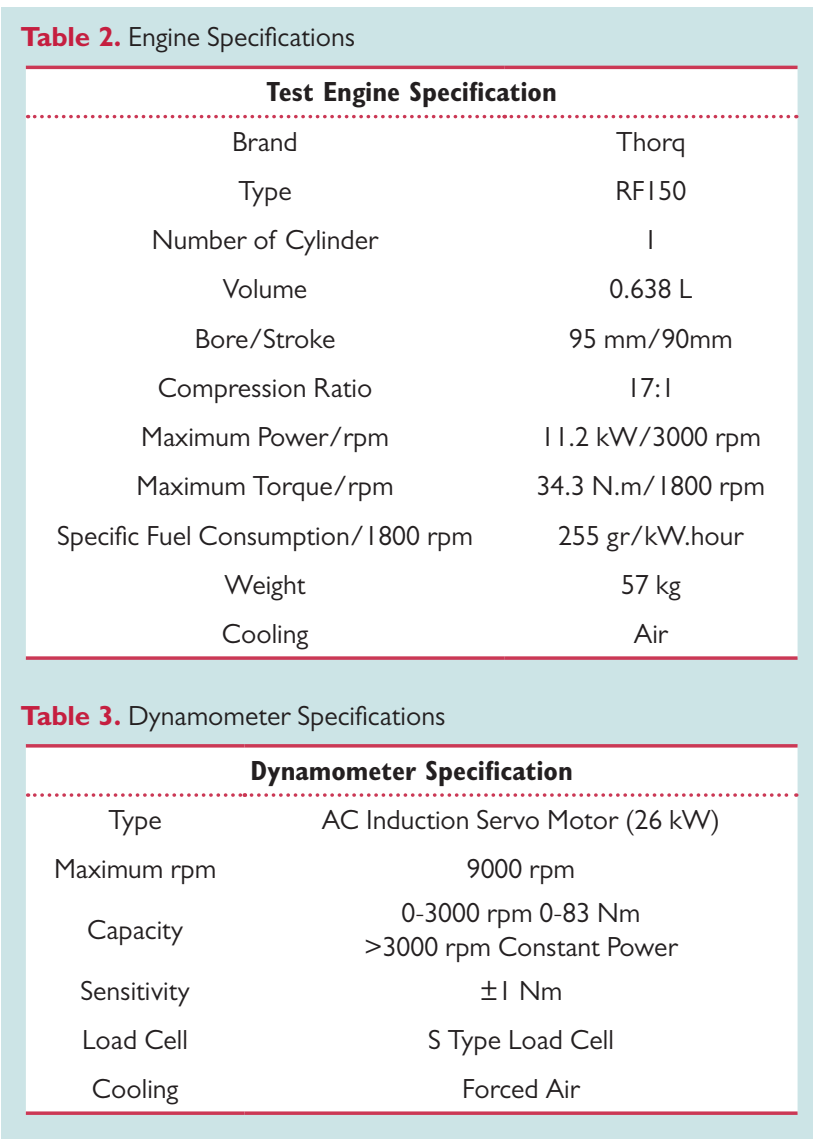

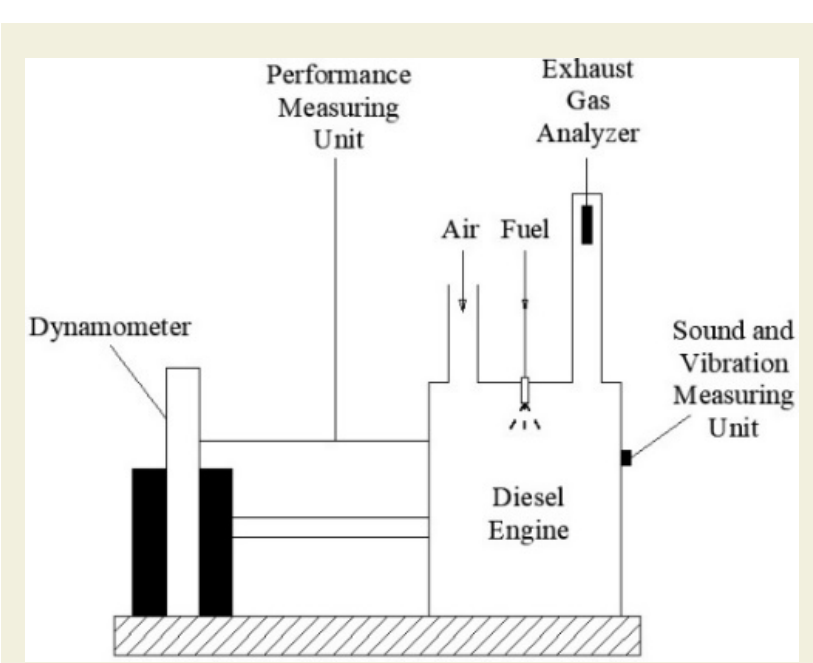

Figure 2. Test-rig (Diesel Engine, AC Dynamometer, Performance Measuring System, Emission Device, Noise and Vibration Measuring System, Accelerometer, Microphone)

MRU Air Delta $1600 \mathrm{~V}$ mobile exhaust gas analyzer was utilized to reveal emission characteristics of the engine operated with various test fuels. The technical features of the emission instrument are also given in Table 4. Soundbook ${ }^{\text {tx }}$ universal portable measuring system run by SAMURAI v2.6 software from SINUS Messtechnik $\mathrm{GmbH}$, an accelerometer (model no: 356A33) which was fastened on the engine block and a microphone set from GRAS (46AF) which was located at 1 meter away from the engine was employed to extract engine vibration and 
sound data. Vibration and sound measurement device specifications can be found in the following Tables 5 and 6.

$a_{\text {total }}$ value were calculated as shown in the following equation in order to make comparative analyses for vibration acceleration.

$$
a_{w}=\sqrt{\frac{1}{T} \int_{0}^{T} a_{w}^{2}(t) d t}
$$

where; $a_{w}\left(m / s^{2}\right)$ and $\mathrm{T}$ are weighted acceleration and measurement time, respectively.

$$
a_{\text {total }}=\sqrt{a_{\text {vertical }}^{2}+a_{\text {lateral }}^{2}+a_{\text {longitudinal }}^{2}}
$$

where; $a_{\text {vertical, }} a_{\text {lateral }}$ and $a_{\text {longitudinal }}$ are acceleration in the vertical axis, lateral axis, and longitudinal axis, correspondingly.

\section{RESULTS AND DISCUSSIONS}

\section{I. Fuel Property Results}

Diesel fuel properties and nanoparticle-containing test fuels were measured and compared to diesel fuel in accordance with EN 590 which is given in Table 7.

From the table, prominent change is not observed in the physicochemical properties of the fuel mixtures. However, viscosity, the heating value, and the cetane number of blend fuels increased slightly, especially at the higher concentration level of nanoparticles.

\subsection{Performance and Emission Results}

The average of SFC, CO, $\mathrm{HC}$, and $\mathrm{NO}_{\mathrm{x}}$ values for test fuels are tabulated in Table 8 .

\subsection{Specific fuel consumption}

SFC is one of the prominent performance characteristics of an engine and is described as the ratio of the mass flow rate of fuel to a unit power of an internal combustion engine. Fig. 3 represents the variation of SFC with engine speed for all test fuels. The maximum average reduction in SFC was obtained for DNiAg50 in comparison with conventional diesel fuel. The lower SFC was obtained at

\begin{tabular}{cc} 
Table 4. Emission measurement device specifications \\
\hline \multicolumn{1}{c}{ Emission Device Specifications } \\
\hline $\mathrm{CO}$ & $0-10 \%$ \\
$\mathrm{CO}_{2}$ & $0-20 \%$ \\
$\mathrm{HC}$ & $0-20000 \mathrm{ppm}$ \\
$\mathrm{O}_{2}$ & $0-22 \%$ \\
$\mathrm{NO}$ & $0-4000 \mathrm{ppm}$ \\
$\mathrm{NO}_{2}$ & $0-1000 \mathrm{ppm}$ \\
Lambda & $0-9,99$ \\
Accuracy & According to $\mathrm{OIML}$-class I \\
Ambient Temperature & $5{ }^{\circ} \mathrm{C}-45^{\circ} \mathrm{C}$ \\
Exhaust Gas Temperature & Max $650{ }^{\circ} \mathrm{C}$ \\
\hline
\end{tabular}

Table 5. Vibration measurement device specifications

\begin{tabular}{cc}
\hline Accelerometer Specifications \\
\hline Sensitivity ( $\pm 10 \%)$ & $1.02 \mathrm{mV} /\left(\mathrm{m} / \mathrm{s}^{2}\right)$ \\
Measurement Range & $\pm 4905 \mathrm{~m} / \mathrm{s}^{2} \mathrm{pk}$ \\
Frequency Range ( $\pm 5 \%$ ) (y or z axis) & 2 to $10000 \mathrm{~Hz}$ \\
Frequency Range ( $\pm 5 \%$ ) (x axis) & 2 to $7000 \mathrm{~Hz}$ \\
Resonant Frequency & $\geq 55 \mathrm{kHz}$ \\
Broadband Resolution (I to I0000 Hz) & $0.04 \mathrm{~m} / \mathrm{s}^{2} \mathrm{rms}$ \\
Non-Linearity & $\leq 1 \%$ \\
Transverse Sensitivity & $\leq 5 \%$ \\
\hline
\end{tabular}

Table 6. Sound measurement device specifications

\begin{tabular}{cc}
\hline Microphone Set Specifications \\
Frequency range $( \pm 2 \mathrm{~dB})$ & 3.15 to $20 \mathrm{kHz}$ \\
$\begin{array}{c}\text { Dynamic range lower and upper limit } \\
\text { with GRAS preamplifier }\end{array}$ & $17-142 \mathrm{~dB}(\mathrm{~A})$ \\
Set sensitivity @ $250 \mathrm{~Hz}( \pm 2 \mathrm{~dB})$ & $50 \mathrm{mV} / \mathrm{Pa}$ \\
Power supply min. to max. (single/ & 28 to $120 \mathrm{~V} / \pm \mathrm{I} / 4$ to \\
balanced) & $\pm 60 \mathrm{~V}$ \\
Temperature range, operation & -30 to $70{ }^{\circ} \mathrm{C}$ \\
Influence of axial vibration @। m/s $/ \mathrm{s}^{2}$ & $62 \mathrm{~dB} \mathrm{re} 20 \mu \mathrm{Pa}$ \\
\hline
\end{tabular}

$50 \mathrm{ppm}$ concentration of each additive which is $3.37 \%$ and $2.7 \%$ for $\mathrm{DNiAg} 50$ and $\mathrm{DMnAg} 50$, respectively. Accordingly, the decrement trend in SFC was observed with increasing in concentration of blend fuels according to the base diesel fuel owing to the catalytic effect of nanoparticles, enhanced heating value of test fuels, the momentum of fuel jet, and rate of penetration which is re-

\begin{tabular}{|c|c|c|c|c|c|c|c|c|}
\hline Fuel & $\begin{array}{l}\text { Cetane } \\
\text { number }\end{array}$ & $\begin{array}{c}\text { Density }\left(\mathrm{kg} / \mathrm{m}^{3}\right) \\
\text { at } 15^{\circ} \mathrm{C}\end{array}$ & $\begin{array}{c}\text { Viscosity } \\
\left(\mathrm{mm}^{2} / \mathrm{s}\right) \text { at } 40^{\circ} \mathrm{C}\end{array}$ & $\begin{array}{l}\text { Heating value } \\
\mathrm{MJ} / \mathrm{kg}\end{array}$ & $\begin{array}{l}\text { Pour } \\
\text { point } \\
\left({ }^{\circ} \mathrm{C}\right)\end{array}$ & $\begin{array}{l}\text { Cloud } \\
\text { point } \\
\left({ }^{\circ} \mathrm{C}\right)\end{array}$ & $\begin{array}{l}\text { Flash point } \\
\qquad\left({ }^{\circ} \mathrm{C}\right)\end{array}$ & $\begin{array}{c}\text { Copper strip } \\
\text { corrosion }\end{array}$ \\
\hline EN590 & $\min 51$ & $820-840$ & $2-4.5$ & - & - & - & $\min 55$ & la \\
\hline Diesel & 56.277 & 841.1 & 2.701 & 44.66 & -24 & -3 & 90 & la \\
\hline DNiAg25 & 57.370 & 841.7 & 2.803 & 45.19 & -24 & -3 & 90 & $\mathrm{la}$ \\
\hline DNiAg50 & 57,632 & 842.2 & 2.827 & 45.32 & -25 & -2 & 96 & la \\
\hline DMnAg25 & 57.302 & 841.4 & 2.789 & 45.12 & -24 & -3 & 84 & la \\
\hline $\mathrm{DMnAg} 50$ & 57.529 & 841.9 & 2.816 & 45.17 & -25 & -2 & 92 & la \\
\hline
\end{tabular}
sponsible for homogeneous dispersion of air-fuel mixture 
Table 8. The mean SFC, CO, HC, and NOx variations of test fuels

Fuels

$\begin{array}{llll}\text { Parameters } & \mathrm{DNiAg} 25 & \mathrm{DNiAg} 50 & \mathrm{DMnAg} 25 \\ \mathrm{DMnAg} 50\end{array}$ Change (\%)*

$\begin{array}{ccccc}\mathrm{SFC}(\mathrm{g} / \mathrm{kWh}) & -2.27 & -3.37 & -1.4 \mathrm{I} & -2.7 \\ \mathrm{CO}(\%) & -7.28 & -9.79 & -7.14 & -9.48 \\ \mathrm{HC}(\mathrm{ppm}) & -18.2 & -21.66 & -13.17 & -19.24 \\ \mathrm{NO}_{\mathrm{x}}(\mathrm{ppm}) & -5.52 & -14.62 & -4.35 & -6.56\end{array}$

*\% changes are given with respect to reference diesel fuel

inside the cylinder. From the results, the combination of $\mathrm{AgNO}_{3}-\mathrm{Ni}\left(\mathrm{NO}_{3}\right)_{2} \cdot 6 \mathrm{H}_{2} \mathrm{O}$ has a stronger effect than $\mathrm{Ag}$ $\mathrm{NO}_{3}-\mathrm{Mn}\left(\mathrm{NO}_{3}\right)_{2} \cdot \mathrm{xH}_{2} \mathrm{O}$ in terms of reduction in SFC for the same dosage. This situation might be ascribed to the fact that nanoparticles containing $\mathrm{AgNO}_{3}$ have a higher surface-to-volume ratio, improved catalytic activity results in a shorter ignition delay for preferable combustion characteristics and thus decrease in SFC. These findings are in good harmony with the studies conducted by (Arockiasamy and Anand 2015; Keskin, Gürü and Altıparmak 2007; Banapurmath et al. 2014).

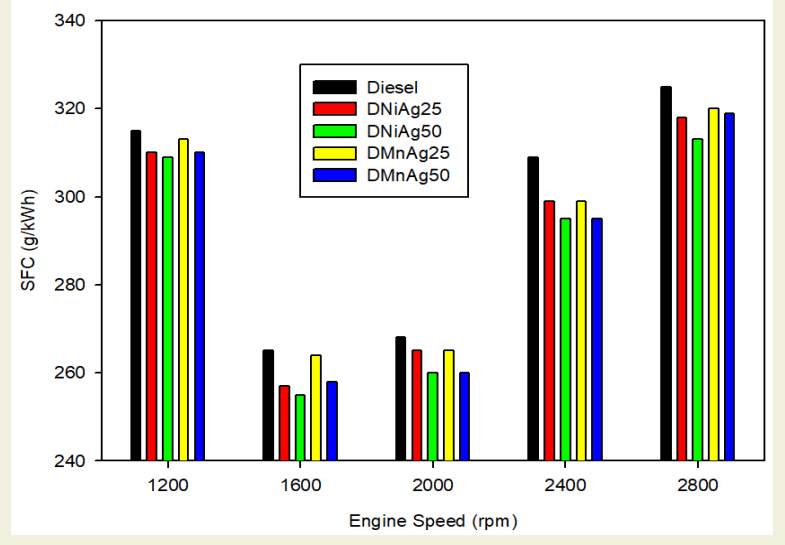

Figure 3. Variation of SFC with respect to engine speed

\subsection{CO Emission}

The reason for $\mathrm{CO}$ formation is air deficiency, reactant concentration, and insufficient swirl in the combustion chamber and results in insufficient $\mathrm{CO}_{2}$ conversion of all carbon. The fuel quality also affects the $\mathrm{CO}$ emission, especially, higher cetane number of nanoparticle blended fuel which is responsible for better heat transfer rate and shorter ignition delay which leads to the reduction in $\mathrm{CO}$ emission $[15,16]$. CO variation towards engine speed is depicted in Fig. 4.

The average reductions in $\mathrm{CO}$ emission are found to be 9.79\%, 9.48\%, 7.28\% and 7.14\% for DNiAg50, DMnAg50, DNiAg25, DMnAg25, respectively. From the findings, a reduced trend of $\mathrm{CO}$ was observed for bimetallic nanoparticles with the increment of nanoparticle concentration level. However, some researchers reported that higher dosage nanoparticles addition into diesel fuel could worsen the engine performance and hence rise in exhaust emissions $[4,17,18]$. It is seen that the availability of $\mathrm{AgNO}_{3}$ in the mixture contributed to the reduction of $\mathrm{CO}$ emission for whole test fuels.

It is observed that the reason for a decrease in $\mathrm{CO}$ emission is thanks to the high oxygen content and large surface area of nanoparticles which triggered an improved combustion process. Saraee et al. [19] reported that silver nanoparticles blended fuel decreased the equivalence ratio because of the improved atomization and better air-fuel mixture leading to a decline in $\mathrm{CO}$ emission. Fangsuwannarak and Triratanasirichai [20] demonstrated that the supplement of metal-based nanoparticles comes out a decrease in $\mathrm{CO}$ emission due to higher oxidation of carbon causing complete combustion.

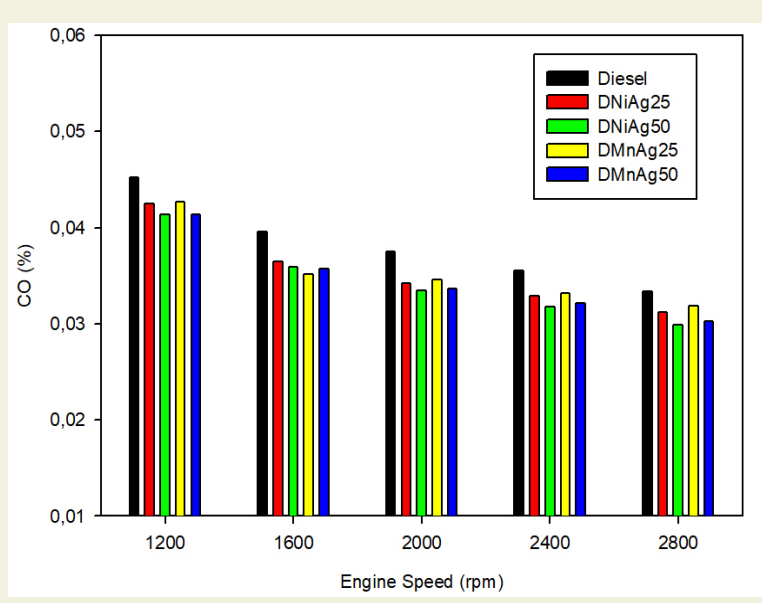

Figure 4. Variation of $\mathrm{CO}$ with respect to engine speed

\subsection{HC Emission}

Many factors affecting $\mathrm{HC}$ emission can be ordered as a non-stoichiometric air-fuel ratio, flame quenching, and deposits on the cylinder walls [21]. Especially, insufffcient temperature caused unburned fuels. In addition, fuel type, engine adjustment, and design are the others factors affecting the content of hydrocarbons [15]. Most of the researchers revealed that hydrocarbon emission was decreased with fuels containing nanoparticles. Fig. 5 presents the change in $\mathrm{HC}$ emission versus engine speed. From the Figure, average reductions for $\mathrm{HC}$ emission are found for DNiAg50, DmnAg50, DniAg25, DmnAg25 which are $21.66 \%, 19.24 \%, 18.2 \%$ and $13.17 \%$, respectively. Among the nanoparticles dispersed test fuels, Dni$\mathrm{Ag} 50$ presents a considerable reduction in $\mathrm{HC}$ emission. When the oxygenated additive $\mathrm{AgNO}_{3}$ is added into test fuels, $\mathrm{HC}$ emission further decreased depending on the nanoparticle concentration. This statement is due to the fact that $\mathrm{AgNO}_{3}$ nanoparticles supply more oxygen reducing unburnt $\mathrm{HC}$. It is evident that $\mathrm{AgNO}_{3}$ was determined to be a higher oxidizing agent among the other test fuels. This result is confirmed by [21]. Furthermore, it was revealed that the addition of nanoparticles caused the reduction of ignition delay owing to better catalytic activity, 


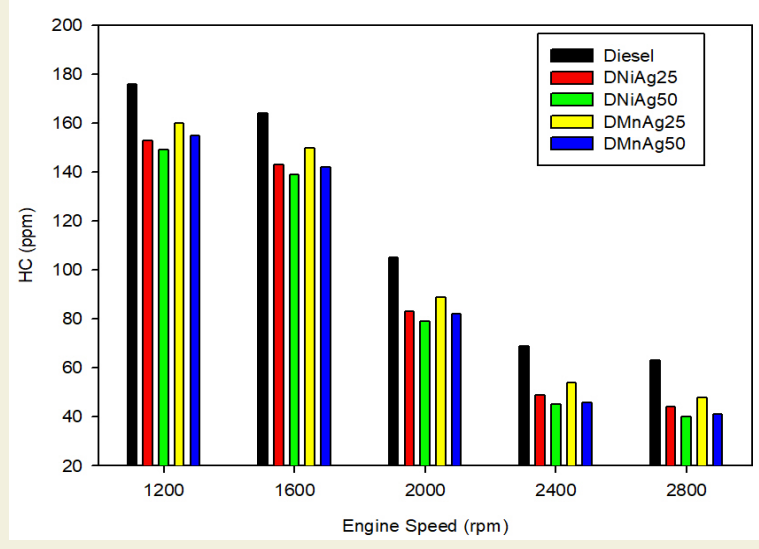

Figure 5. Variation of $\mathrm{HC}$ with respect to engine speed

and also reduced $\mathrm{HC}$ emission [22].

\subsection{NO Emission}

Nitrogen oxides constituted from nitric oxide (NO) and nitrogen dioxide $\left(\mathrm{NO}_{2}\right)$ are depending upon many factors such as higher combustion temperature, ignition delay, and the amount of abundant oxygen presence for chemical reaction with nitrogen above $1600{ }^{\circ} \mathrm{C}$ in the diesel engine. Various metal-based additives like manganese oxide $(\mathrm{MnO})$ and copper oxide $(\mathrm{CuO})$ were used and add into diesel fuel to be able to enhance the quality of diesel fuel. Accordingly, this leads to more complete burning of fuel and causing a reduction in $\mathrm{NO}_{\mathrm{x}}$ emissions [23]. However, nanoparticles with metallic additives have led to an increase in $\mathrm{NO}_{x}$ emission thanks to the catalyst effect in the combustion process [24]. Fig. 6 illustrates the change in $\mathrm{NO}_{x}$ emission towards engine speed. Whole test fuels with nanoparticles exhibit a decline in $\mathrm{NO}_{x}$ emission at lower engine speeds. But, when the engine speed rises, the $\mathrm{NO}_{\mathrm{x}}$ emission raised with the higher dosage of fuel-containing nanoparticles. Average $\mathrm{NO}_{\mathrm{x}}$ emission for metallic-based nanoparticle decreased by $14.62 \%, 6.56 \%, 5.52 \%$, and $4.35 \%$ for DniAg $50, \mathrm{Dm}$ nAg50, DniAg25, and DmnAg25 in comparison with base diesel fuel. It is seen that the $\mathrm{NO}_{x}$ decreased by $14.62 \%$ for $\mathrm{AgNO}_{3}-\mathrm{Ni}\left(\mathrm{NO}_{3}\right)_{2} \cdot 6 \mathrm{H}_{2} \mathrm{O}$ additives due to the fast evaporation rate which is confirmed by lower exhaust gas temperature [25], higher thermal conductivity, and cetane number of nanoparticles [4,18,26-28]. As a result, it has been determined that the addition of high doses of $\mathrm{AgNO}_{3}$ and $\mathrm{Ni}\left(\mathrm{NO}_{3}\right)_{2} \cdot 6 \mathrm{H}_{2} \mathrm{O}$ to the mixed fuels remarkably reduces the $\mathrm{NO}_{x}$ pollutant.

\subsection{Vibration and Sound Results}

ICEs generate high noise and vibration levels depending on frequencies and these sources have resulted from rotation and piston components of the engine. Vibration and sound levels according to engine speed are illustrated in Figs. 7 and 8. As seen from the figures, there are a slight increase in engine vibration acceleration and SPL with

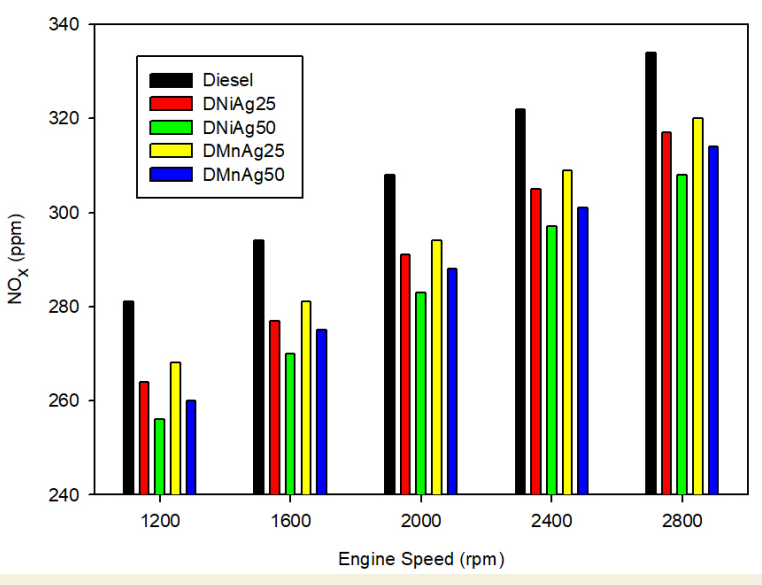

Figure 6. Variation of $\mathrm{NO}_{x}$ with respect to engine speed

the increase in engine speed. However, nanoparticle addition into test fuels decreased the vibration acceleration and SPL level in comparison with diesel fuel, especially at higher engine speeds. However, at low engine speeds, the addition of nanoparticles does not make a significant contribution to vibration reduction as a better combustion efficiency cannot be achieved. Mean engine vibration and noise levels of blend fuels are indicated in Table 9.

Table 9. The average vibration and SPL values of test fuels.

\begin{tabular}{|c|c|c|c|c|}
\hline \multirow{3}{*}{ Parameters } & \multicolumn{4}{|c|}{ Fuels } \\
\hline & DNiAg25 & DNiAg50 & DMnAg25 & DMnAg50 \\
\hline & \multicolumn{4}{|c|}{ Change (\%)* } \\
\hline Vibration $\left(\mathrm{mm} / \mathrm{s}^{2}\right)$ & -2.49 & -3.59 & -1.52 & -2.9 \\
\hline Sound (dB) & -0.95 & -1.96 & -0.93 & -1.54 \\
\hline
\end{tabular}

The average decrement in engine vibration was found to be $3.59 \%$ with $\mathrm{DNiAg} 50$, 2.9\% with $\mathrm{DMnAg} 50,2.49 \%$ with DNiAg25, and $1.52 \%$ with DMnAg25. The parallel results observed for average SPL compared with diesel fuel are also ordered for DNiAg50, DMnAg50, DNiAg25, and DMnAg25 which are 1.96\%, 1.54\%, 0.95\%, and $0.93 \%$, respectively. However, an increase of the sound to $1600 \mathrm{rpm}$ for DNiAg50 was observed in Figure 8. This situation can be attributed to the fluctuations in all cases are within the limits of sensitivity of the instrument. From the results, the same combined effect of $\mathrm{AgNO}_{3}$ and $\mathrm{Ni}\left(\mathrm{NO}_{3}\right)_{2} \cdot 6 \mathrm{H}_{2} \mathrm{O}$ is also valid for the reduction of vibration acceleration and SPL at higher dosage concentrations. These results are also confirmed by [12].

\section{Conclusions}

The paper concentrated on the emissions and vibration characteristics of a single diesel engine fueled metallic-based nanoparticles. The main findings can be summarized as follows.

- Significant change is not observed in the physico- 


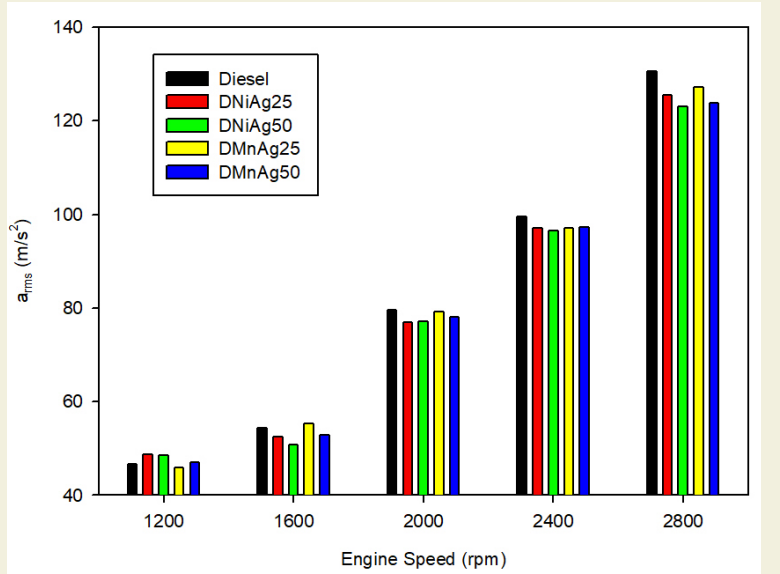

Figure 7. Change in vibration versus engine speed

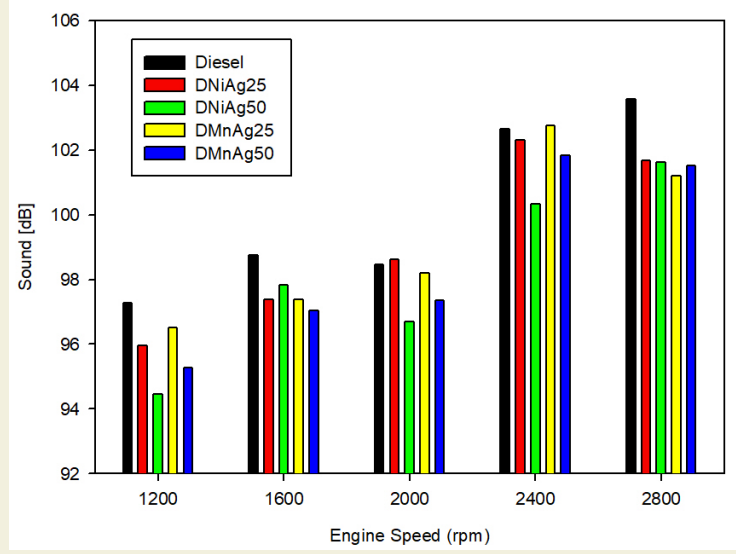

Figure 8. Change in sound level versus engine speed

chemical properties of the test fuels with test fuels containing metallic-based nanoparticles. However, viscosity, the heating value, and the cetane number of blend fuels increased slightly, especially at the higher concentration level of nanoparticles.

- SFC reduced with the addition of nanoparticles for whole test fuels with the rise in concentration levels. Maximum average reduction of SFC was observed for $\mathrm{DNiAg} 50$ as $3.37 \%$ when compared with conventional diesel fuel. This can be ascribed since the catalytic effect of nanoparticles, the enhanced heating value of test fuels, and momentum of fuel jet and rate of penetration which accounts for the homogeneous spread of air-fuel mixture inside the cylinder.

- Emission of $\mathrm{CO}, \mathrm{HC}$, and $\mathrm{NO}_{\mathrm{x}}$ showed a decrement trend and maximum reduction was found for DNiAg50 test fuel. The reason for this reduction is by virtue of high oxygen content and large surface area of nanoparticles, also reduction of ignition delay which causes better catalytic activity, furthermore, fast evaporation rate which is confirmed by lower exhaust gas temperature, higher thermal conductivity and cetane number of nanoparticles.

- Mean engine vibration and noise levels of test fuels escalated with the increment in engine speed. But, when evaluated for whole engine tests, depending on the increase of concentration levels of nanoparticles, there is a slight reduction in terms of vibration and SPL.

In conclusion, it has been determined that silver nitrate doped mixtures have a strong effect in parallel with the increase in nanoparticle concentration levels in terms of performance increase and reduction of emission values.

Future studies are required in order to determine the combined effects of various bimetallic nanoparticle and their optimal dosage in reduction of emission and SPL.

\section{References}

[1] Reşitoglu, I.A., Altinişik, K., Keskin, A., (2015). The pollutant emissions from diesel-engine vehicles and exhaust aftertreatment systems. Clean Technologies and Environmental Policy. 17(1): 15-27. doi: 10.1007/s10098-014-0793-9.

[2] Calik, A. (2017). Pamuk Yağı Biyodizelinin Motor Ses Seviyesine Olan Etkilerinin İncelenmesi. Çukurova Üniversitesi Mühendislik-Mimarlık Fakültesi Dergisi, 32(4), 147-152. https://doi.org/10.21605/cukurovaummfd.371016

[3] Çalık, A. (2018). Hidrojen ile Yakıt Zenginleştirmenin Dizel Motorun Motor Performansı ve Emisyon Özelliklerine Etkisi. Çukurova Üniversitesi Mühendislik-Mimarlık Fakültesi Dergisi, 33(3), 255-262. https://doi.org/10.21605/ cukurovaummfd.504771

[4] Yaşar, A., Keskin, A., Yildizhan, Ş., Uludamar, E., Ocakoğlu, K., (2018). Effects of titanium-based additive with blends of butanol and diesel fuel on engine characteristics. International Journal of Global Warming. 15(1): 38-53. doi: 10.1504/JJGW.2018.091950.

[5] Nanthagopal, K., Kishna, R.S., Atabani, A.E., Al-Muhtaseb, A.H., Kumar, G., Ashok, B., (2020). A compressive review on the effects of alcohols and nanoparticles as an oxygenated enhancer in compression ignition engine. Energy Conversion and Management. 203(October 2019): 112244. doi: 10.1016/j.enconman.2019.112244.

[6] Ozgur, T., Tuccar, G., Uludamar, E., Yilmaz, A.C., Güngör, C., Ozcanli, M., et al., (2015). Effect of nanoparticle additives on NOx emissions of diesel fuelled compression ignition engine. International Journal of Global Warming. 7(4): 487-98. doi: 10.1504/IJGW.2015.070051.

[7] El-Seesy, A.I., Attia, A.M.A., El-Batsh, H.M., (2018). The effect of Aluminum oxide nanoparticles addition with Jojoba methyl ester-diesel fuel blend on a diesel engine performance, combustion and emission characteristics. Fuel. 224(March): 147-66. doi: 10.1016/j.fuel.2018.03.076.

[8] Wu, Q., Xie, X., Wang, Y., Roskilly, T., (2017). Experimental investigations on diesel engine performance and emissions using biodiesel adding with carbon coated aluminum nanoparticles. Energy Procedia. 142: 3603-8. doi: 10.1016/j.egypro.2017.12.251.

[9] Prabu, A., (2018). Nanoparticles as additive in biodiesel on the working characteristics of a DI diesel engine. Ain Shams Engineering Journal. 9(4): 2343-9. doi: 10.1016/j. asej.2017.04.004.

[10] Çalık, A., (2018). Determination of vibration characteristics of a compression ignition engine operated by hydro- 
gen enriched diesel and biodiesel fuels. Fuel. 230(May): 355-8. doi: 10.1016/j.fuel.2018.05.053.

[11] Keskin, A., Yaşar, A., Yıldızhan, Ş., Uludamar, E., Emen, F.M., Külcü, N., (2018). Evaluation of diesel fuel-biodiesel blends with palladium and acetylferrocene based additives in a diesel engine. Fuel. 216(June 2016): 349-55. doi: 10.1016/j. fuel.2017.11.154.

[12] Yaşar, A., Keskin, A., Yıldızhan, Ş., Uludamar, E., (2019). Emission and vibration analysis of diesel engine fuelled diesel fuel containing metallic based nanoparticles. Fuel. 239(November 2018): 1224-30. doi: 10.1016/j. fuel.2018.11.113.

[13] Ağbulut, Ü., Karagöz, M., Sarıdemir, S., Öztürk, A., (2020). Impact of various metal-oxide based nanoparticles and biodiesel blends on the combustion, performance, emission, vibration and noise characteristics of a $\mathrm{Cl}$ engine. Fuel. 270(March). doi: 10.1016/j.fuel.2020.117521.

[14] Yaşar, A., Keskin, A., Tosun, E., Yildizhan, Ş., (2020). Promotional effect of metal based nanoparticles on emission and vibration analysis of diesel engine. International Journal of Automotive Engineering and Technologies. doi: 10.18245/ ijaet.730092.

[15] Reşitoglu, I.A., Altinişik, K., Keskin, A., (2015). The pollutant emissions from diesel-engine vehicles and exhaust aftertreatment systems. Clean Technologies and Environmental Policy. 17(1): 15-27. doi: 10.1007/s10098-014-0793-9.

[16] Khond, V.W., Kriplani, V.M., (2016). Effect of nanofluid additives on performances and emissions of emulsified diesel and biodiesel fueled stationary $\mathrm{Cl}$ engine: $\mathrm{A}$ comprehensive review. Renewable and Sustainable Energy Reviews. 59: 1338-48. doi: 10.1016/j.rser.2016.01.051.

[17] Saxena, V., Kumar, N., Saxena, V.K., (2017). A comprehensive review on combustion and stability aspects of metal nanoparticles and its additive effect on diesel and biodiesel fuelled C.I. engine. Renewable and Sustainable Energy Reviews. 70(June 2016): 563-88. doi: 10.1016/j. rser.2016.11.067.

[18] Khan, S., Dewang, Y., Raghuwanshi, J., Shrivastava, A., Sharma, V., (2020). Nanoparticles as fuel additive for improving performance and reducing exhaust emissions of internal combustion engines. International Journal of Environmental Analytical Chemistry. 00(00): 1-23. doi: 10.1080/03067319.2020.1722810.

[19] Soukht Saraee, H., Jafarmadar, S., Taghavifar, H., Ashraf, S.J., (2015). Reduction of emissions and fuel consumption in a compression ignition engine using nanoparticles. International Journal of Environmental Science and Technology. 12(7): 2245-52. doi: 10.1007/s13762-015-0759-4.

[20] Fangsuwannarak, K., Triratanasirichai, K., (2013). Improvements of Palm Biodiesel Properties by Using Nano-TiO 2 Additive, Exhaust emission and Engine Performance The Romanian Review Precision Mechanics. Optics \& Mechatronics. (43): 111-8.

[21] Kumar, S., Dinesha, P., Ajay, C.M., Kabbur, P., (2020). Combined effect of oxygenated liquid and metal oxide nanoparticle fuel additives on the combustion characteristics of a biodiesel engine operated with higher blend percentages. Energy. 197: 117194. doi: 10.1016/j.energy.2020.117194.

[22] Karthikeyan, S., Elango, A., Prathima, A., (2014). Performance and emission study on zinc oxide nano particles addition with pomolion stearin wax biodiesel of $\mathrm{Cl}$ engine. Journal of Scientific and Industrial Research. 73(3): 187-90.

[23] Lenin, M.A., Swaminathan, M.R., Kumaresan, G., (2013). Performance and emission characteristics of a DI diesel engine with a nanofuel additive. Fuel. 109: 362-5. doi: 10.1016/j.fuel.2013.03.042.

[24] Keskin, A., Gürü, M., Altiparmak, D., (2007). Biodiesel production from tall oil with synthesized $\mathrm{Mn}$ and $\mathrm{Ni}$ based additives: Effects of the additives on fuel consumption and emissions. Fuel. 86(7-8): 1139-43. doi: 10.1016/j. fuel.2006.10.021.

[25] Arockiasamy, P., Anand, R.B., (2015). Performance, combustion and emission characteristics of a D.I. diesel engine fuelled with nanoparticle blended jatropha biodiesel. Periodica Polytechnica Mechanical Engineering. 59(2): 88-93. doi: 10.3311/PPme.7766.

[26] Granier, J.J., Pantoya, M.L., (2004). Laser ignition of nanocomposite thermites. Combustion and Flame. 138(4): 373-83. doi: 10.1016/j.combustflame.2004.05.006.

[27] Kumar, M.V., Babu, A.V., Kumar, P.R., (2019). Influence of metal-based cerium oxide nanoparticle additive on performance, combustion, and emissions with biodiesel in diesel engine. Environmental Science and Pollution Research. 26(8): 7651-64. doi: 10.1007/s11356-018-04075-0.

[28] Kumar Patel, H., Kumar, S., (2017). Experimental analysis on performance of diesel engine using mixture of diesel and bio-diesel as a working fuel with aluminum oxide nanoparticle additive. Thermal Science and Engineering Progress. 4(x): 252-8. doi: 10.1016/j.tsep.2017.09.011. 